Sotala, D. J., and C. M. Kirkpatrick. 1973. Foods of whitetailed deer, Odocoileus virginianus, in Martin County, Indiana. American Midland Naturalist 89:281-286.

Sperry, J. S., N. M. Holbrook, M. H. Zimmerman, and M. T. Tyree. 1987. Spring filling of xylem vessels in wild grapevine. Plant Physiology 83:414-417.

Stiles, E. W. 1982. Fruit flags: two hypotheses. American Naturalist 120:500-509.

Walters, M. B., and P. B. Reich. 2000. Seed size, nitrogen supply and growth rate affect tree seedling survival in deep shade. Ecology 81:1887-1901.

Ward, J. K., and J. Kelly. 2004. Scaling up evolutionary responses to elevated $\mathrm{CO}_{2}$ : lessons from Arabidopsis. Ecology Letters 7:427-440.

WDNR (Wisconsin Department of Natural Resources). 2004. Southern forest communities. Ecological landscapes of Wisconsin-Ecosystem Management Planning Handbook, HB1805.1. Wisconsin Department of Natural Resources, Madison, Wisconsin, USA.

Zotz, G., N. Cueni, and C. Körner. 2006. In situ growth stimulation of a temperate zone liana (Hedera helix) in elevated $\mathrm{CO}_{2}$. Functional Ecology 20:763-769.

Ecology, 89(2), 2008, pp. 585-587

(C) 2008 by the Ecological Society of America

\section{BIOMASS AND TOXICITY RESPONSES OF POISON IVY (TOXICODENDRON RADICANS) TO ELEVATED ATMOSPHERIC $\mathrm{CO}_{2}$ : REPLY}

Jacqueline E. Mohan, ${ }^{1,2,3,4,9}$ Lewis H. Ziska, ${ }^{5}$ Richard B. Thomas, ${ }^{6}$ Richard C. Sicher, ${ }^{5}$ Kate George, ${ }^{5}$ James S. Clark, ${ }^{1,7}$ and William H. Schlesinger ${ }^{1,7,8}$

Manuscript received 24 April 2007; accepted 20 June 2007; final version received 18 September 2007. Corresponding Editor: B. A. Hungate.

${ }^{1}$ Duke University, Department of Biology, Durham, North Carolina 27708 USA.

${ }^{2}$ Harvard University, Department of Organismic and Evolutionary Biology, Cambridge, Massachusetts 02138 USA.

${ }^{3}$ The Ecosystems Center, Marine Biological Laboratory, Woods Hole, Massachusetts 02543 USA.

${ }^{4}$ Odum School of Ecology, University of Georgia, Athens, Georgia 30602 USA.

${ }^{5}$ USDA, Agricultural Research Service, Crop Systems and Global Change Laboratory, Beltsville, Maryland 20705 USA.

${ }^{6}$ West Virginia University, Department of Biology, Morgantown, West Virginia 26506 USA.

${ }^{7}$ Nicholas School of the Environment and Earth Sciences, Duke University, Durham, North Carolina 27708 USA.

${ }^{8}$ Institute of Ecosystem Science, Millbrook, New York 12545 USA.

${ }^{9}$ E-mail: jmohan@uga.edu
Schnitzer et al. (2008) contrast results from a recent experimental study documenting increased growth of poison ivy (Toxicodendron radicans) in the free-air carbon dioxide enrichment (FACE) facility in the Duke Forest, North Carolina (Mohan et al. 2006), to an uncontrolled observational study finding decreased abundance of poison ivy in Wisconsin forests between 1959 and 2005 (Londré and Schnitzer 2006). Schnitzer et al. (2008) accurately point out that controlled field studies may not always emulate long-term responses in uncontrolled "real world" forests. The lack-of-change in overall vine abundance in the Wisconsin forests is in contrast to previous studies showing recent increases in the abundance of vines in temperate (Myster and Pickett 1992, Dillenburg et al. 1995, Allen 2007, Allen et al. 2007) and tropical forests (Laurance et al. 2001, Phillips et al. 2002, 2005, Wright et al. 2004), as well as our Duke FACE poison ivy study that suggests increases in vine growth at elevated atmospheric $\mathrm{CO}_{2}$. Data from the Duke experiment highlight the impact of deer and rabbit herbivory for understory plants, and a recent deerexclosure study (Forrester et al. 2006) cited by Schnitzer et al. (2008) suggests that the difference between our studies may stem from mammalian herbivory on poison ivy. We additionally address the idea that understory light limitation may explain the differential responses of poison ivy in the two studies.

Londré and Schnitzer (2006) compare abundances of woody vines (lianas), including poison ivy, in 14 southern Wisconsin forests in 2005 with abundances previously recorded in 1959 . The authors found that the overall abundance of vines was not different between the two years, and that poison ivy was actually less abundant in 2005 than it was in 1959. Schnitzer et al. (2008) point out that any observed differences between these two years could be due to many potential causes, such as successional development, degree of fragmentation, increasing temperatures, rising atmospheric $\mathrm{CO}_{2}$, or increasing deer populations, as well as land use histories, nitrogen deposition, increasing atmospheric ozone, and other changes over time including a host of unknown variables.

Schnitzer et al. (2008) present several mechanisms to potentially reconcile differences in the results from the Duke FACE experiment with their observations in the Wisconsin forests, including deer herbivory and light limitation. We believe mammalian herbivory is largely responsible for the different responses of poison ivy in the two studies, as the Duke poison ivy plants were protected from deer and rabbits while the Wisconsin plants were not. The negative impacts of overly abundant mammalian herbivores on forest understory plants are well known (Leopold et al. 1947, Alverson et al. 1988, DeSteven 1991, Alverson and Waller 1997, Augustine and Jordan 1998, Opperman and Merenlender 2000, Terborgh et al. 2001). As Schnitzer et al. 


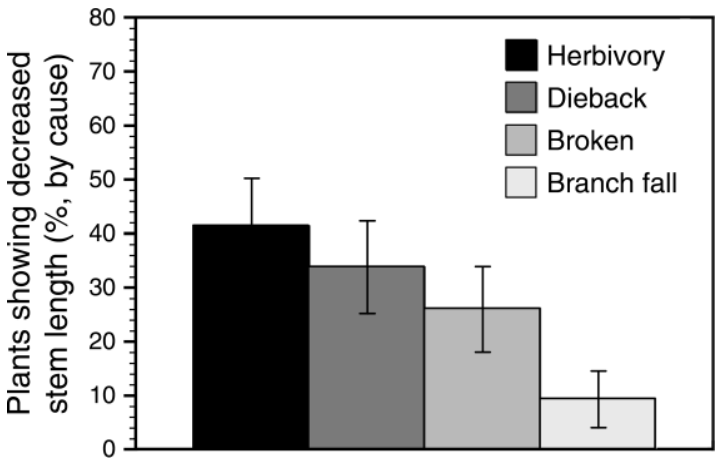

FIG. 1. Causes of decreased stem lengths (heights) between autumn 1996 and spring 1997 (the initiation of the Duke FACE experiment) in the FACE forest understory. Bars represent percentages (mean $\pm \mathrm{SE}$ ) of "shrunken plants" (understory trees, shrubs, and vines) that exhibited symptoms of mammalian herbivory, stem dieback, broken stems, or stems snapped by fallen canopy tree branches. When only poison ivy stems were analyzed, the percentage of stems preyed upon by mammals increased to $88 \%$. Mammalian herbivory data presented here may be biased toward rabbit herbivory; rabbits possess both upper and lower incisors and cut stems at a $45^{\circ}$ angle, leaving very distinctive bite signatures. Deer lack upper incisors and tear or rip plant stems; deer herbivory can be difficult to distinguish from other causes of stem breakage, so the "broken" data likely include stems that were eaten by deer. "Dieback" represents stems with the terminal portion still present but dead and is often a sign of fungal (or other) pathogens or drought stress.

(2008) report, a two- to fivefold increase in Wisconsin deer populations has occurred over the last 40 years, and the deer population in North Carolina tripled between 1983 and 1998 (data available online), ${ }^{10}$ particularly in forests like the Duke FACE, which are adjacent to urban and suburban development (information available online). ${ }^{11}$ Poison ivy is a favorite forage crop of many wildlife species including white-tailed deer and rabbits (Gillis 1971, Hoppes 1988, Penner et al. 1999, Suthers et al. 2000). Forrester et al. (2006) found that poison ivy abundance increased fourfold after 16 years of deer exclusion (due to the small sample size, none of the plant species in this study exhibited statistically significant responses to deer exclusion), and poison ivy was one of only three species whose abundance declined significantly in response to increasing deer populations before the exclosure study began. Similarly, recent work in two temperate South Carolina forests, where habitat change and human hunting has maintained stable or even declining deer populations since the mid-1990s (data available online), ${ }^{12}$ documents increased density and

${ }^{10}\langle$ http://www.env.duke.edu/forest/forest/wildlife.htm $\rangle$

11 http://www.ncwildlife.org/pg07_wildlifespeciescon/ pg7b4.htm $\rangle$

12 /http://www.dnr.sc.gov/news/Yr2007/june25/ june18_harvest.html $\rangle$ growth of poison ivy during the last $12-22$ years (Allen 2007, Allen et al. 2007).

At the Duke FACE experiment we are finding that mammalian herbivores mediate some plant responses to atmospheric $\mathrm{CO}_{2}$ (Figs. 1 and 2). Poison ivy plants accessible to deer and rabbits show no statistically significant effect of $\mathrm{CO}_{2}$ on survivorship. However, these unprotected plants exhibit much higher mortality rates than their herbivore-protected (caged) counterparts (Fig. 2). The high mortality rates of poison ivy plants available to herbivores, and the potential for such plants growing at elevated $\mathrm{CO}_{2}$ to have higher mortality than ambient-grown plants, may help explain the declining poison ivy cover in Wisconsin forests.

Schnitzer et al. (2008) also reason that the understory of the older Wisconsin forests may offer a lower light environment than the Duke Forest, and that greater light limitation may have increased the mortality of poison ivy plants and reduced their abundance in the northern forests. Schnitzer et al. present no data for light intensities in the Wisconsin forests, but understory light levels at the loblolly pine plantation at FACE, often $<2$ $3 \%$ full sunlight (Mohan et al. 2007), are unlikely to be substantially different from the Wisconsin stands.

The works of Londré and Schnitzer (2006) and Schnitzer et al. (2008) highlight the limitations of both controlled experiments and purely observational studies,

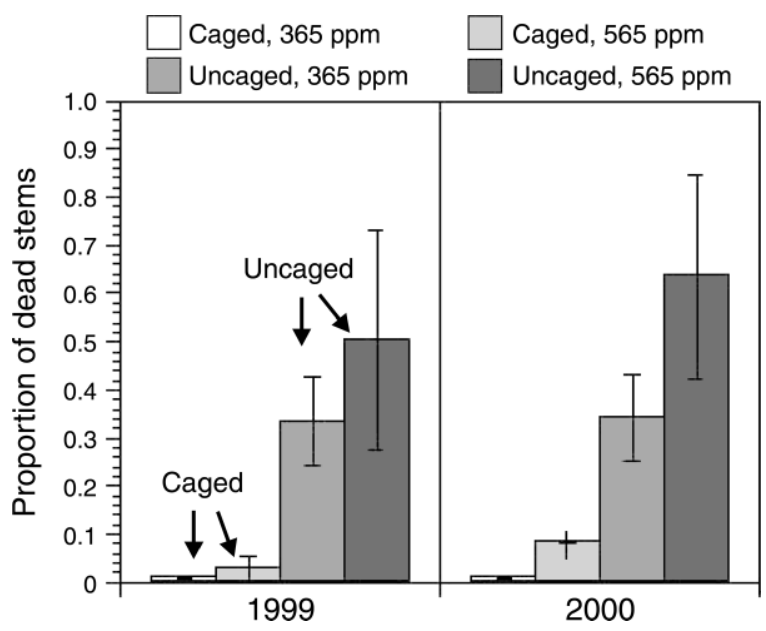

FIG. 2. Cumulative mortality (mean \pm SE) of poison ivy stems (ramets) growing in the Duke Forest FACE experiment ( $n=3$ plots/treatment). "Caged" plants (paler gray) are plants protected from mammalian herbivores; "uncaged" plants are available to both deer and rabbit herbivores. Note the high mortality of uncaged plants at both $\mathrm{CO}_{2}$ concentrations. Whether or not a plant was accessible by herbivores highly influenced its mortality probability $(P<0.0001)$. Although there is no significant $\mathrm{CO}_{2}$ effect on mortality, there is an important $\mathrm{CO}_{2} \times$ cage interaction $(P=0.026)$, suggesting that the effects of herbivores on poison ivy mortality is influenced by atmospheric $\mathrm{CO}_{2}$ concentrations. Caged plants growing at ambient $\mathrm{CO}_{2}$ had $0 \%$ mortality in years 1999 and 2000 . 
and the value of long-term ecological data. Clearly, uncontrolled observational studies can reveal important changes in ecosystem structure over time and may suggest potential reasons for differential behavior of natural ecosystems, but controlled experiments are required to determine the underlying, mechanistic reasons for change. By combining the observational work in Wisconsin and the controlled $\mathrm{CO}_{2}$ and herbivory experiments at Duke, we gain insights regarding the importance of top-down control for structuring ecological systems in an increasing- $\mathrm{CO}_{2}$ world.

\section{Acknowledgments}

We thank J. M. Melillo, P. T. Frankson, and K. J. Lenoir for helpful comments on this manuscript. We thank D. LeBauer for critical field assistance at Duke FACE. This work was enhanced by discussions with M. Dietze, J. Hille Ris Lambers, I. Ibañez, S. LaDeau, J. McLachlan, R. Peet, J. Pippen, B. Strain, and M. Wolosin. The manuscript was improved by suggestions from an anonymous reviewer. This work was supported by the Office of Science (BER), U.S. Department of Energy, Grant Number DE-FG02-95ER62083 and Terrestrial Ecosystems and Global Change (TECO) Grant Number DE-F602-97ER62463.

\section{Literature cited}

Allen, B. P. 2007. Vegetation dynamics and response to disturbance in floodplain forest ecosystems with a focus on lianas. Dissertation. Ohio State University, Columbus, Ohio, USA.

Allen, B. P., R. R. Sharitz, and P. C. Goebel. 2007. Are lianas increasing in importance in temperate floodplain forests in the southeastern United States? Forest Ecology and Management 242:17-23.

Alverson, W. S., and D. M. Waller. 1997. Deer populations and the widespread failure of hemlock regeneration in northern forests. Pages 280-297 in W. J. McShea, H. B. Underwood, and J. H. Rappole, editors. The science of overabundance: deer ecology and population management. Smithsonian Institution Press, Washington, D.C., USA.

Alverson, W. S., D. M. Waller, and S. L. Solheim. 1988. Forests too deer: edge effects in northern Wisconsin. Conservation Biology 2:348-358.

Augustine, D. J., and P. A. Jordan. 1998. Predictors of whitetailed deer grazing intensity in fragmented deciduous forests. Journal of Wildlife Management 62:1076-1085.

DeSteven, D. 1991. Experiments on mechanisms of tree establishment in old-field succession: seedling survival and growth. Ecology 72:1076-1088.

Dillenburg, L. R., A. H. Teramura, I. N. Forseth, and D. F. Whigham. 1995. Photosynthetic and biomass allocation responses of Liquidambar styraciflua (Hamamelidaceae) to vine competition. American Journal of Botany 82:454-461.

Forrester, J. A., D. J. Leopold, and H. B. Undersood. 2006. Isolating the effects of white-tailed deer on the vegetation dynamics of a rare maritime American holly forest. American Midland Naturalist 156:135-150.

Gillis, W. T. 1971. The systematics and ecology of poison-ivy and the poison-oaks (Toxicodendron, Anacardiaceae). Rhodora $73: 72-152,161-237,370-443,465-540$.

Hoppes, W. G. 1988. Seedfall pattern of several species of birddispersed plants in an Illinois (USA) woodland. Ecology 69: 320-329.

Laurance, W. F., D. Pérez-Salicrup, P. Delamônica, P. M. Fearnside, S. D'Angelico, A. Jerozolinski, L. Phol, and T. E. Lovejoy. 2001. Rain forest fragmentation and the structure of Amazonian liana communities. Ecology 82:105-116.

Leopold, A., L. K. Sowls, and D. L. Spencer. 1947. A survey of over-populated deer ranges in the United States. Journal of Wildlife Management 11:162-177.

Londré, R. A., and S. A. Schnitzer. 2006. The distribution of lianas and their change in abundance in temperate forests over the past 45 years. Ecology 87:2973-2978.

Mohan, J. E., J. S. Clark, and W. H. Schlesinger. 2007. Longterm $\mathrm{CO}_{2}$ enrichment of a forest ecosystem: implications for forest regeneration and succession. Ecological Applications 17:1198-1212.

Mohan, J. E., L. H. Ziska, W. H. Schlesinger, R. B. Thomas, R. C. Sicher, K. George, and J. S. Clark. 2006. Biomass and toxicity responses of poison ivy (Toxicodendron radicans) to elevated atmospheric $\mathrm{CO}_{2}$. Proceedings of the National Academy of Sciences (USA) 103:9086-9089.

Myster, R. W., and S. T. A. Pickett. 1992. Dynamics of associations between plants in ten old fields during 31 years of succession. Journal of Ecology 80:291-302.

Opperman, J. J., and A. M. Merenlender. 2000. Deer herbivory as an ecological constraint to restoration of degraded riparian corridors. Restoration Ecology 8:41-47.

Penner, R., G. E. Moodie, and R. J. Staniforth. 1999. The dispersal of fruits and seeds of poison ivy, Toxicodendron radicans, by ruffed grouse, Bonasa umbellus, and squirrels, Tamiasciurus hudsonicus and Sciurus carolinensis. Canadian Field Naturalists 113:616-620.

Phillips, O. L., et al. 2002. Increasing dominance of large lianas in Amazonian forests. Nature 418:770-774.

Phillips, O. L., R. Vásquea Martínez, A. Monteagudo Mendoza, T. R. Baker, and P. Núñez. 2005. Large lianas as hyperdynamic elements of the tropical forest canopy. Ecology 86:1250-1258.

Schnitzer, S. A., R. A. Londré, J. Klironomos, and P. B. Reich. 2008. Biomass and toxicity responses of poison ivy (Toxicodendron radicans) to elevated atmospheric $\mathrm{CO}_{2}$ : Comment. Ecology 89:581-585.

Suthers, H. B., J. M. Bickal, and P. G. Rodewald. 2000. Use of successional habitat and fruit resources by songbirds during autumn migration in central New Jersey. Wilson Bulletin 112:249-260

Terborgh, J., L. Lopez, P. Nunez, M. Rao, G. Shahabuddin, G. Orihuela, M. Riveros, R. Ascanio, G. H. Adler, T. D. Lambert, and L. Balbas. 2001. Ecological meltdown in predator-free forest fragments. Science 294:1923-1926.

Wright, S. J., O. Calderon, A. Hernandez, and S. Paton. 2004. Are lianas increasing in importance in tropical forests? A 17 year record from Panama. Ecology 85:484-489. 